\title{
TEMUAN DUA KAPAK PERUNGGU DARI TUBAN
}

\section{Oleh: Goenadi Nitihaminoto}

Temuan benda-benda perunggu di Indonesia umumnya terdiri dari kapak, nekara, bejana, beberapa jenis senjata, arca berbentuk manusia dan hewan serta perhiasan-perhiasan yang berupa hiasan telinga, gelang, cincin dan sebagainya. Benda-benda itu ditemukan secara tersebar di beberapa daerah di Indonesia.

Di Tuban pada tahun 1977 pernah ditemukan beberapa benda perunggu, yaitu 2 kapak, 5 tombak dan 1 nekara kecil. Benda-benda itu tepatnya ditemukan di desa Guwaterus yang termasuk kecamatan Montong. Lokasi temuan berada di tengah hutan jati, dalam lapisan tanah liat merah. Desa Guwaterus terletak lebih kurang $20 \mathrm{Km}$ di sebelah selatan pantai utara atau $\pm 35 \mathrm{Km}$ di sebelah barat-daya Tuban. Barangbarang temuan itu sekarang disimpan di Museum Empu Tantular Surabaya, dengan nomor 4100-4105.

Dua kapak perunggu itu ukurannya tidak sama, yang satu lebih besar (No. 4101) dari kapak yang lain (No. 4102). Kapak yang lebih besar berukuran panjang $11,4 \mathrm{Cm}$, lebar bagian tajaman 8,0 Cm, lebar ujung tangkai 4,1 Cm dan tebal $0,25 \mathrm{Cm}$; sedang kapak yang lain berukuran panjang 9,5 Cm, lebar bagian tajaman 6,3 Cm, lebar ujung tangkai 3,0 $\mathrm{Cm}$ dan tebal 0,25 $\mathrm{Cm}$. Kedua kapak itu mempunyai ujung tangkai berbentuk ekor burung seriti dengan penampang lintang bulat telur dan keduanya tidak berhias. Pada salah satu permukaannya terdapat garis yang mengikuti kedua tepian yang melengkung. Ujung bagian tajaman yang tebalnya $0,10 \mathrm{Cm}$ berbentuk cembung dan secara keseluruhan menyerupai bentuk kipas. Kedua bagian tepian di kiri dan kanan dari kapak itu terdapat garis sambungan sebagai bekas cetakan setangkup.

Ciri-ciri di atas dapat disamakan dengan tipe IIA pada pen-tipe-an kapak perunggu yang dilakukan oleh R.P. Soejono. Kapak tipe ini di Indonesia ditemukan di beberapa daerah seperti Sumatera Selatan, Jawa Barat, Jawa Tengah, Jawa Timur, Bali dan Flores (Soejono, 1976: 235236). Sebelum itu van der Hoop dan van Heekeren telah mengkelompokkan kapak perunggu ke dalam beberapa bagian, tetapi hasilnya masih tampak agak umum bila dibanding dengan klasifikasi Soejono. Van der Hoop mengkelompokkan kapak perunggu menjadi beberapa macam, yaitu kapak corong, senjata-senjata yang bersifat seremonial dan tajak. H.R. van Heekeren membuat klasifikasi lebih terperinci dari van der Hoop, tetapi masih menitik beratl an pada contoh-contoh kapak yang bagus saja, yaitu tipe umum kap $k$ corong, kapak tembilang atau tajak (Soejoro, 1972: 1; 1976: 235-236: van Heekeren 1958: 8-11).

Persamaan-fersamaan bentuk kapak t rsebut selair dapat dicari di beberapa daerah di Indonesia, di luar Indonesia persamaannya 
dapat dilihat di beberapa daerah di Asia Tènggara, Cina dan sebagainya.

Di Filipina kapak perunggu tipe IIA ditemukan pada ekskavasi si guagua Palawan, seperti gua Tabon, Duyong dan Batu Puti (F. Landa Jocano, 1975: 112). Di Thailand kapak corong dan benda-benda perunggu lainnya ditemukan secara tersebar di beberapa daerah. Di Wang Pho misalnya, kapak corong ditemukan bersama-sama kapak batu yang diupam, manik-manik kornelian, gerabah berisi kerangka manusia dan sebagainya. Jenis kapak corong hampir dikenal di seluruh dunia, seperti Yunnan, Indochina, Siberia, Rusia Selatan dan lembah Danube. Hanya di India dan di Timur Tengah saja kapak corong tidak dikenal sama sekali (Van Heekeren et al, 1967: 118-119).

Di Rembang, yang terletak $\pm 100 \mathrm{Km}$ di sebelah barat laut Tuban diberitakan pernah ditemukan kapak perunggu seremonial. Di Bojonegoro, yang terletak $\pm 60 \mathrm{Km}$ di sebelah barat-daya Tuban $( \pm 35 \mathrm{Km}$ dengan jarak pintas), pernah ditemukan kapak corong (van Heekeren, 1958: 8-10). Kapak perunggu temuan dari Rembang dilukiskan sebagai kapak upacara dengan hiasan yang bagus dan disebut chandrasa. Chandrasa, yaitu kata yang diambil dari istilah pewayangan (van Heekeren, 1958: 10); Soejono, 1972: 1).

Bojonegoro dan Rembang merupakan daerah yang berbatasan dengan Tuban. Tuban dalam pembagian administrasi pemerintahan termasuk karesidenan Bojonegoro.

Perunggu, merupakan logam yang tidak murni yang diperoleh dengan cara mencampur beberapa logam lain dengan persentase tertentu yang besarnya tidak sama pada setiap unsurnya. Perunggu dihasilkan dengan mencampur tembaga $(\mathrm{Cu})$, timah hitam $(\mathrm{Pb})$ dan timah putih (Sn) dengan perbandingan tertentu. Kadang-kadang unsur pembentuk perunggu itu ditambah dengan logam lain, yaitu besi (Fe). Unsur besi sebagai bahan campuran perunggu terdapat di Ta-p'o-na, Hsiang-yun, Yunnan. Dari 11 sample artefak terpilih, 2 artefak perunggu mengandung unsur besi (Kwang-chih Chang, 1972: 429). Unsur-unsur perunggu selain besi ialah zinc (Zn), magnesium (Mg), silicon (Si), phosphor (P) dan sulphur (S).

Di antara unsur-unsur itu, tembaga merupakan unsur yang dominan. Logam tembaga tidak selalu ditemukan pada setiap negara baik di negara-negara di Asia Tenggara maupun di negara-negara di luar itu. Dengan demikian tembaga merupakań logam yang langka sehingga sukar diperoleh. Di Indonesia, tembaga ditemukan di beberapa daerah, yaitu di kepulauan Sunda Besar, Timor dan Irian Jaya dan merupakan bahan yang tidak mudah diperoleh (Soejono, 1976: 241). Unsur lain seperti timah, meskipun tidak merupakan unsur menonjol - tetapi merupakan unsur penentu - tidak setiap negara memilikinya. Di Filipina logam pertama yang muncul ialah tembaga. Kenyataan menunjukkan 
bahwa di sana banyak sumber-sumber tembaga yang ditemukan tetapi tidak ada timah. Bagaimanapun juga tembaga digunakan secara luas sebagai materi dalam pembuatan peralatan, yang digunakan untuk perhiasan dan perunggu muncul secara simultan bersama tembaga (F. Landa Jocano, 1975: 109-110). Mengingat sukarnya untuk memperoleh perunggu maka benda-benda perunggu yang sudah tidak terpakai biasanya dituang kembali untuk membuat benda-benda perunggu yang baru (Soejono, 1976: 241).

Kesukaran memperoleh bahan perunggu menyebabkan harga perunggu menjadi mahal dan dengan demikian tidak setiap orang bisa memilikinya. Sehingga benda-benda perunggu akan menaikkan status pemiliknya di mata masyarakat. Oleh karena itu kapak perunggu dari Tuban khususnya, dan dari daerah-daerah lain umumnya jelas berfungsi sebagai benda seremonial dan bukan sebagai benda praktis. Kapak perunggu tidak mungkin dipakai sebagai benda praktis mengingat logam itu merupakan logam yang getas sehingga tidak sesuai dengan fungsi dan tujuan dari pembuatan alat itu.

Dua kapak perunggu dari Tuban ditemukan bersama-sama dengan nekara dan tombak yang semuanya terbuat dari perunggu. Bendabenda itu tampaknya sengaja dikubur. Maksud penguburan bendabenda itu belum diketahui dengan pasti tetapi dapat diduga bahwa penguburan benda-benda itu untuk tujuan tertentu dengan merahasiakan tempatnya. Mungkin benda itu dianggap keramat sehingga tidak begitu mudah ditemukan oleh orang yang tidak dikehendaki.

Corak umum kapak perunggu Cina adalah dengan penampang lintang persegi pada ujung tangkainya. Satu-satunya temuan kapak perunggu yang dicurigai mendapat pengaruh langsung dari Cina ialah kapak perunggu yang ditemukan di dekat Palembang karena mempunyai penampang persegi pada ujung tangkainya (van Heekeren, 1958: 9). Bentuk penampang serupa itu contohnya dapat dilihat pada kapak perunggu dengan ujung tangkai berbentuk ekor burung seriti di situs Ch'ing-yun, Kwangtung (Kwang-chih Chang, 1972: 392).

Kapak perunggu dari Tuban yang berpenampang lintang bulat telur pada bagian ujung tangkainya, dapat dikatakan bahwa kapak tersebut tidak mendapat pengaruh langsung dari Cina.

Tuban telah dikenal sejak lama sebagai bandar kuna, sehingga lemuan kapak perunggu tersebut dapat dicurigai sebagai barang impor, karena tidak ditemukan bukti-bukti penuangan perunggu di daerah itu. Berdasarkan letak geografis yang menguntungkan bagi Tuban sebagai kota pelabuhan, maka temuan kapak corong dari Bojonegoro dan Rembang mungkin berasal dari daerah Tuban. Hal yang perlu diingat ialah letak Bojonegoro tidak terlalu jauh dengan Tuban dan merupakan daerah yang berbatasan. Demikian juga temuan chandrasa dari Rembang, van Heekeren sendiri memberikan keterangan pada 
lampiran foto sebagai temuan dari Tuban. Hal ini mungkin terjadi kekeliruan pencatatan sewaktu benda tersebut diserahkan ke museum atau si pencatat benda itu menerima informasi yang salah tentang asal temuan kedua benda tersebut. Apabila dugaan ini benar, maka dapat dibayangkan betapa besar potensi masa perunggu di Tuban yang akan membawa pengaruh kepada keadaan sosial penduduknya di masa itu.

Di Asia Tenggara logam mulai dikenal kira-kira tahun 3000-2000 S.M. Di Non Nok Tha (Muang Thai) pernah ditemukan kapak perunggu yang berdasarkan analisa C-14 berumur 3000 S.M. Di Filipina bendabenda perunggu ditemukan pada 400 S.M. Di Indonesia penggunaan logam dikenal sejak beberapa abad sebelum Masehi (Soejono, 1976: 221).

Kedua kapak perunggu dari Tuban tersebut belum dapat ditentukan umurnya secara pasti, meskipun pemakaian logam secara umum telah dapat diperkirakan, dalam hubungannya dengan penyebaran benda-benda perunggu di Asia Tenggara.

Karena dari bentuk penampang kapak tersebut menunjukkan penga ruh yang tidak langsung dari Cina, maka kapak itu mungkin berasal dari masa yang lebih muda dari pertanggalan yang diperkirakan untuk Indonesia tersebut. 


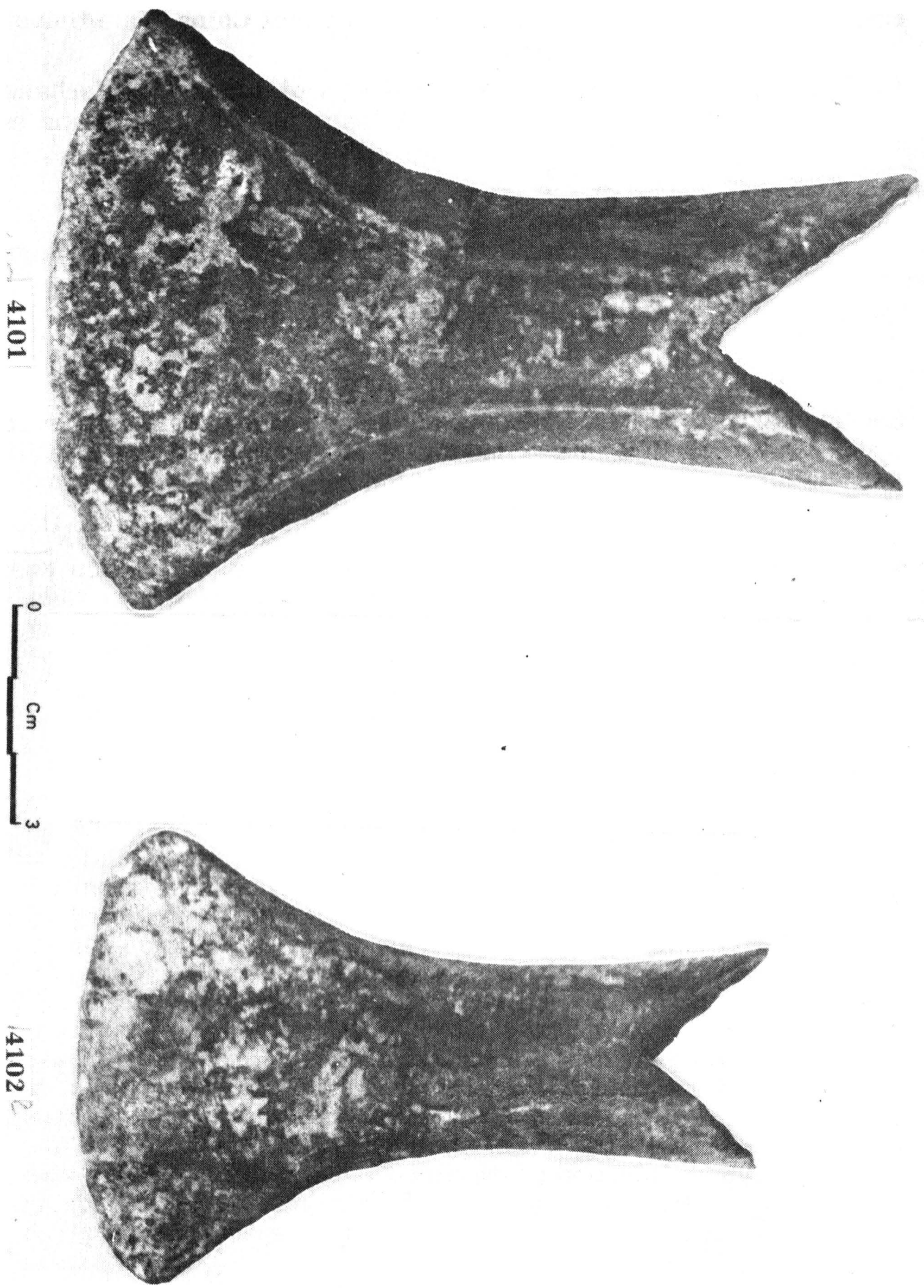

Temuan dua Kapak Perunggu dari Guwaterus, Tuban (Jawa Timur). 


\section{Kepustakaan:}

Chang, Kwang-chih: The Archaeology of Ancient China, Yale Univer1972 sity Press.

Heekeren, H.R. van : The Bronze - Iron Age of Indonesia, Verhand. 1958 van het Koninklijk Instituut voor Taal,- Land en Volkenkunde, deel XXII, 's-Gravenhage - Martinus Nijhoff.

Heekeren, H.R. Van and Counteigil Knuth:

1967 Archaeological Excavation in Thailand Volume I, Munksgaard, Copenhagen.

Jocano, F. Landa : Philippine Prehistory, Philippine Center For An1975 vanced Studies, University of The Philippines System, Diliman, Quezon City.

Șoejono, R.P.

: The Distribution of Types of Bronze Axes in In1972 donesia, Bulletin of The Archaeological Institute of the Republic of Indonesia No. 9, Djakarta.

1976 Prasejarah Indonesia, Sejarah Nasional I, Dept. P dan K, Jakarta. 